\title{
Strategic Human Resource Management: Insights from the International Hotel Industry
}

\begin{abstract}
In the strategic human resource management (SHRM) field three approaches have dominated, namely, the universal or best-practice, best-fit or contingency and resourcebased view (RBV). This study investigates evidence for the simultaneous or mixed adoption of these approaches by eight case study firms in the international hotel industry. Findings suggest there is considerable evidence of the combined use of the first two approaches but that the SHRM RBV approach was difficult to achieve by all companies. Overall, gaining differentiation through SHRM practices was found to be challenging due to specific industry forces. The study identifies that where companies derive some competitive advantage from their human resources and HRM practices they have closely aligned their managers' expertise with their corporate market entry mode expertise and developed some distinctive, complex and integrated HRM interventions, which have a mutually reinforcing effect.
\end{abstract}

Keywords: International Human Resource Management; Strategic Human Resource Management; Differentiation; Competitive advantage 


\section{Strategic Human Resource Management: Insights from the International Hotel Industry}

\subsection{Introduction}

SHRM has emerged as the prominent designation of people management over the past three decades (Boxall \& Purcell, 2008; Thite, Wilkinson \& Shah, 2012; Zheng, 2013). With their own discernible perspectives, the universal or best practice, best-fit or contingency and the resource-based view (RBV) approaches (Boxall \& Purcell, 2008; Pinnington, 2011) have dominated the field. Whilst empirical research has tended to explore SHRM from one of these specific approaches, more recent theoretical arguments have suggested that companies are unlikely to adhere solely to a singular approach due to the complexity of factors and forces acting upon firms, instead adopting these approaches simultaneously (Boxall \& Purcell, 2008; 2011; Marler, 2012). Limited empirical exploration has taken place to explore firms' simultaneous adoption of these SHRM approaches to achieve competitive advantage through human resources (Boselie et al., 2009). Where research has been undertaken, findings have highlighted the importance of industry level analysis (Pauuwe, 2009; Paauwe \& Boselie, 2003) and called for further empirical work to explore how international firms within industries manage their human resources competitively. This study responds to this demand and analyses the adoption of hybrid SHRM approaches by firms in one industry.

While the SHRM literature recognizes the importance of exogenous and endogenous factors in shaping firm's people management practices and approaches, the international human resource management (IHRM) literature highlights that cultural and institutional environment factors which influence, facilitate and constrain HRM across borders 
(Edwards et al., 2010; Zheng, 2013). However, limited research has focused on understanding how international companies within specific industries adopt SHRM approaches and HRM practices to deliver competitive success (Boselie et al., 2009; Marler, 2012; Zheng, 2013) by balancing these exogenous and endogenous factors. As the spotlight of this study is the strategic and international human resource management (SIHRM) of international managers, the expatriates and inpatriates who lead international subsidiaries, the strategic approaches are given centre stage in the exploration of the literature.

The aim of this research is to explore evidence of the hybrid version of SHRM approaches through case studies of companies in the international hotel industry. This industry presents a particularly apposite sectoral context where there is a long and continued history of internationalization and the rhetoric suggests 'a hotel is only as good as its manager'. Unit or subsidiary managers have traditionally been seen as 'strategic human resources' responsible for creating profitable units through their leadership and expertise in hospitality-specific and generic-business management skills (Miao, Adler \& Xu, 2011). It is also an industry, dominated by companies with vast portfolios of hotels across the world using low risk and control entry modes, typically management contracts and franchises (Xiao, O’Neill \& Mattila, 2012) which has increased the skills and expertise demanded of such managers (Magnini, 2008; Gannon, et al., 2010; Hodari \& Sturman, 2014). As such, the importance of mutually beneficial relationships between hotel companies, their partners and property owners and (master) franchisees further highlights the importance of effectively managing and developing skilled and experienced hotel managers. By undertaking a qualitative approach, and securing unprecedented executive level access into eight of the world's largest international hotel companies (IHCs), this study explores the deployment and 
development of strategic human resources by evaluating a hybrid version of SIHRM approaches. In so doing, it focuses upon the links between dominant fields in the literature: strategy, SHRM, IHRM and market entry models, which have previously received little co-ordinated attention (Pisani, 2009).

Initially, this article evaluates the SHRM approaches and the empirical and theoretical evidence on IHRM highlighting evidence for a hybrid SIHRM approach. An overview of the research design is then provided alongside the rationale for the methods deployed. The findings from the companies' SIHRM approaches are reported and evaluated in relation to the proposed hybrid SIHRM approaches. The opportunities and limitations to building and sustaining competitive advantage through international (hotel) unit managers, as strategic human resources, is assessed. Finally, a discussion of the main contributions and limitations of this study, as well as the managerial, theoretical and research implications, conclude this article.

\subsection{Approaches to Strategic Human Resource Management (SHRM)}

Exploring the three main SHRM approaches typically begins with an exploration of the universalist or best practice SHRM approach where companies are encouraged to achieve competitive advantage by adopting sophisticated or 'high performance' HRM practices for their human resources (Pfeffer, 1998). However, disagreements between researchers on what is meant by 'sophisticated' HRM, the exact practices required and the limitations of the empirical evidence has resulted in considerable criticism (Boxall \& Purcell, 2011). Claims that the 'superior' HRM practices associated with the best practice SHRM approach can be adopted across different industrial and national boundaries regardless of diverse cultural conventions and values, and political and social and economic histories and institutions, have led to further denunciation (Boxall 
\& Purcell, 2008; Kaufman, 2014). However, outright criticisms of the 'best practice' SHRM approach have evolved to recognize that within industries there may be certain HRM practices, which are indispensable (Boxall \& Purcell, 2008; 2011) and known as 'table stakes'. Such shared practices are adopted by all organizations to show their legitimate membership of an industry and are recognized as an adaptation of the 'best practice' SHRM approach (Bjorkman, 2006; Leonard-Barton, 1995).

The second SHRM approach 'best-fit' proposes that companies' market positions and strategies determine their HRM policies and practices. A range of theories on the 'best fit' SHRM approach have developed including those which link specific strategy decisions and choices to HRM practices and policies (Schuler \& Jackson, 1987) to more complex models (Fombrun, Tichy \& Devanna, 1984; Beer, et al., 1984) which incorporate wider corporate characteristics (strategies, positions, portfolio characteristics) to determine HRM practices. The limitations of the 'best fit' SHRM approach revolve around its concentration on external market positioning and the challenges of achieving competitive advantage where other organizations within the same sector pursue similar strategies and market positions (Boxall \& Purcell, 2011).

Finally, the RBV SHRM approach is suggested as an alternative to the best practice and best-fit SHRM approaches. It differs from the previous approaches because it proposes that creating competitive advantage is achieved via the leveraging of valuable, rare, inimitable, non-substitutable and rent achieving (human) resources (Barney, 2001; Morris, Snell \& Wright, 2006). Several studies provide empirical evidence that employees can fulfill these criteria to realize competitive advantage through human resources by creating human capital advantage (Marchington, Carroll \& Boxall, 2003). 'Strategic human resources' or 'rainmakers' are the most valuable human resources who 
specifically fulfill the RBV criteria and contribute significant added value to their employers' companies. Commentators have determined that HRM practices can become strategic assets/resources just like the human resources they set out to manage (Boxall \& Purcell, 2011) but only where companies develop idiosyncratic and interdependent HRM practices which capitalize on their proprietary knowledge and transfer it effectively across the workforce. The focus of the RBV approach, on exploiting internal resources to achieve competitive advantage, is then a departure from the best-fit SHRM approach as it attempts to overcome the external and prescriptive views of the best-fit approach (Morris et al., 2006).

Amidst criticisms of these three SHRM approaches each has some value and integrity; however, they represent ideal types which are unlikely to provide companies with a level-headed resolution to their pursuit of competitive advantage via their human resources or HRM practices (Boselie, et al., 2009; Marler, 2012; Zheng, 2013). Rather it seems that companies may instead use a 'hybrid', combined and simultaneous version of the three SHRM approaches in the attempt to understand and balance the external pressures of their industry and competitive set to conform and internal pressures to differentiate. Such insights have been supported further by the work of Teece (2007) and Foss (2011) where the arguments for the dynamic capabilities and microfoundations approaches have been explicated. This hybrid version of the three SHRM approaches is a departure from the autonomous way that these approaches are typically viewed and also highlights the importance of industry dynamics and isomorphism on the development of bundles of HRM practices used to satisfy the 'table stakes' best practice SHRM approach (Boselie et al., 2009; Boxall \& Purcell, 2008). 


\subsection{International SHRM Approaches}

In the international SHRM arena similar limitations of the three main SHRM approaches have been compounded by additional pressures to customize and standardise practices dependent upon local and parent company cultural and institutional factors. For example, the wholesale adoption of 'sophisticated' HRM practices, in line with the best practice SHRM approach, has been roundly critiqued (Brewster, 2006; 2007) due to the deep-rooted national institutional and cultural conventions to people management across nations. However, this does not mean that within a nation all industries have the same HRM practices (Boon et al., 2009). Indeed the IHRM literature can be accused of disproportionately focusing upon the differences between parent and host country cultures and institutions without appreciating the diversity across industry sectors within nations (Marler, 2012; Kaufman, 2014). Boselie, Paauwe \& Richardson's study (2003) shows different 'table stake' HRM practices within the hospital, local government and hotels sector within the same country (The Netherlands) and highlights the value of a hybrid approach to understanding SIHRM where industry context and national cultural and institutional factors all impact upon people management practices.

Within the IHRM area, much of the research conducted has been based upon the best-fit or contingent SHRM approach, though once again such research has focused upon the influence of national differences as well as strategic models (Bartlett \& Ghoshal, 1989; 2000). The main thrust of the strategic dimension to IHRM has revolved around the question of whether HRM practices are customized (to local practices) or standardized (across the company) when firms operate internationally. For example: the models of international orientation (Heenan \& Perlmutter, 1979); product life-cycle phases (Adler \& Ghadar, 1990); and international responsiveness versus integration (Bartlett \& 
Ghoshal, 1989; 2000) are based upon strategic choice arguments derived from the strategic management field.

There have been attempts to develop more nuanced descriptions of SIHRM by analyzing the contingency of specific factors. International versions of the best-fit SHRM approach suggest HRM practices are more likely to be standardized where: they are aimed at managers (Easterby-Smith et al., 1995; Rosenzweig, 2006); there is a high level of parent and subsidiary interdependence; market entry modes involve full or partial ownership (Edwards et al., 2010); companies originate from the USA or Japan (as opposed to Europe) (Ferner \& Quintanilla, 1998); the host country the company enters is less 'culturally distant' from its own country of origin; and their business is embedded in the national business system (Boselie et al., 2003). More recently a four influences framework identifying; country of origin, parent dominance, international integration and host country effects emerged from the cultural, institutional and market based pressures companies face (Edwards et al., 2010). However, once again critics identify similar limitations associated with the external focus of these best-fit type of SIHRM so it is useful to consider the internally focused RBV approach within the IHRM area (Boxall \& Purcell, 2011; Zheng, 2013).

Several authors have adopted the RBV approach in their IHRM investigations (Zhong et al., 2012; Bonache \& Zarraga-Oberty, 2008; Harvey, Novicevic \& Speier, 2000) highlighting its strength as the ability to shed light on the relationship between competitive advantage and expatriates due to the importance of international assignees in the deployment of tacit knowledge across markets. This literature highlights the 'rainmaker' status of expatriates and inpatriates, and their management, in international 
organizations where knowledge transfer is critical to their organizations' success (Bonache \& Zarraga-Oberty, 2008).

In summary then the hybrid version of SIHRM approaches offers a valuable way of understanding how companies deal with the need to simultaneously conform (to national and industrial conventions on managing human resources) and differentiate (through distinctive, integrated and added value HRM practices) in the pursuit of competitive advantage across complex national and industrial contexts (Boxall \& Purcell, 2011). This hybrid standpoint may also allow a more subtle appreciation of SIHRM as it permits a more balanced view of the patterns of internal and external factors shaping companies' attempts to strategically manage their human resources (Boon et al., 2009), overcoming the often domineering influence of specific national cultural and institutional differences. Having highlighted the gaps in the literature and made the case for exploring the hybrid version of SIHRM approaches within the international hotel industry, the design of this study is now outlined.

\subsection{Research Design}

A multi-case study strategy (Thomas, 2011; Patton, 2002) was adopted to achieve cross case analysis of the SIHRM approaches employed in the international hotel industry. Using an industry definition of global operations based on companies with hotels on at least four out of the six economically viable continents, as a purposive sample technique (Bryman \& Bell, 2007; Saunders et al., 2000), nine companies were invited to participate in the research. They were contacted through the research teams' existing professional networks. Subsequent merger activity meant that eight companies accepted the invitation, on the basis that their participation would be anonymized. Company, analysts' and consultancy reports were used to identify the size and scale of portfolios. 
The final set of eight companies highlights the range across the industry with companies varying in size (from 2000 plus hotel units to under 50), internationalization (between 20 and 70 plus countries), nature of brands (solely luxury brands to brands at all market levels) and methods of international growth (ownership, management contracts and franchises).

Senior human resource executives of these eight IHCs were pinpointed as the main respondents to the study in line with Brewster's (2007) argument that a key role for corporate HR is the management of strategic human resources. The authors' personal experiences and contacts in the industry also verified these executives (typically Senior Vice President of Human Resources) as responsible for the deployment and development of hotel managers as strategic human resources. The company case studies were constructed from four strands of data collection (Patton, 2002). Firstly, company and industry archives and documentation were used to analyze the portfolios of the IHCs. Secondly after discussions with a Human Resources director a short, multiplechoice questionnaire was developed to facilitate access through gatekeepers, engage relevant executive participants in the study and inform the subsequent interview conversations. The two-page questionnaire was designed to cover areas which the literature suggested were appropriate in terms of managing international management resources and the frequency and criteria for deploying these practices (see Appendix 1). The responses from these brief questionnaires led to the subsequent development of the interview questions. The questions were as follows;

\section{How does an individual become an international hotel general manager in your company?}

Aimed to elicit data about how general managers were viewed and valued within their companies, their characteristics, qualities, and competences to be displayed and their contributions to the achievement of international goals.

\section{How does your company manage the careers of its hotel managers?}


Aimed to establish the organisational and specifically people management practices used to manage hotel managers including recruitment, selection, succession planning, training and development, performance appraisals, contractual aspects and talent management.

3. How does your company ensure you will have the right calibre and number of hotel general managers to realise your corporate strategy?

Aimed to ascertain the organisational arguments for the practices and policies adopted in managing international hotel general managers in relation to the companies' international strategies. It also hoped to elicit the organisational competencies and knowledge developed and used in realising competitive advantage through key human resources.

While there were only three main questions the interviews with senior executives lasted on average four hours. The interviews with other Human Resource team members were typically shorter and more focused on their specific areas of expertise, for example, talent database use. These interactions also included requests for company documentation, opportunities to observe meetings and day-to-day activities in these teams. The access to archive strategy and HRM materials included HRM policies, performance appraisal forms, organizational charts, training manuals, company newspapers, job descriptions and succession planning charts, as well as demonstrations of talent bank databases. Alongside the interviews these other insights provided additional context and depth to the research data (Thomas, 2011). Subsequent to the fieldwork visits follow-up telephone calls helped clarify some of the company documentation and interview discussions with participants.

The eight cases were developed into narratives and analysed manually. Pattern and theme analysis were used initially with descriptive coding highlighting specific activities and associations between HRM practices and approaches and company characteristics, within and then across the cases, and their associated documents (Patton, 2002). The theoretical relationships arising from the data and initial coding were 
derived from further interpretive coding and analytic coding with the extant literature used to draw conclusions.

\subsection{The SHRM Approaches in International Hotel Companies}

The results showed strong evidence of consistent similarities in the HRM practices deployed by the firms. The initial questionnaire results indicated that specific interventions were being deployed across the sample to manage the quantity and quality of subsidiary managerial resources. In the company cases, built upon the interviews and documents, these similarities were borne out and were particularly evident in how managers were 'seen' by their corporate employers. There were also some differentiating HRM practices apparent, which only a few companies (or one company) adopted, and that were viewed to provide particular organisational benefits by their executive advocates.

\section{INSERT TABLE 1 HERE}

\subsection{Core HRM interventions in international hotel companies}

The second column of Table 1 summarizes the similar or core HRM interventions. All the HR executives saw their unit managers as strategic human resources or rainmakers (Marchington et al., 2003; Boxall \& Steeneveld, 1999) fundamental to business success. All unit managers were charged with being key players in their local business community and as the companies' representatives, often at different market levels too. Industry transformations were bringing new knowledge and skills to bear where broader business and leadership skills were valued over traditional craft skills and knowledge. In addition company growth through the use of management contracts, with the properties owned by external investors, emphasized the importance of unit managers' abilities to 
manage different stakeholders' interests, as well as the expectations of their corporate employers.

Amongst the common HRM practices, interventions which allowed the companies to reinforce their brand standards and promote their version of hotel products and services across international markets were of particular importance. While there are arguments that some of these HRM practices formed the basis of generic best practice; namely training, contractual arrangements and performance appraisal, the others could be seen as 'table stake' practices particular to the international hotel industry itself. Table 1 summarizes the six areas so the strong internal labour market favored by all the companies was symptomatic of the firms' views that familiarization and inculcation to the corporate and brand ethos and operating standards were fundamental. The interventions in the areas of corporate communications highlighted the challenges of geographic spread and ownership as particularly important in the international hotel industry. The documentation provided emphasized the companies' intense desire to communicate to their human resources with the cases all using web pages, brochures, newsletters and booklets as well as travelling executives to further reinforce company service standards and goals as identified by the Anglo-American Premium executives' comments "At the Vice President and divisional director levels we're always travelling, listening to what are people are saying and telling them about what's happening across the company." The nature of the international hotel industry, with its specific market entry modes and the diverse geographical spread of properties, results in a set of common HRM challenges being identified. All the respondents reported the property owners involved in management contracts interfering in human resource decisions and practices to some degree. Owners from specific regions (namely the Middle East, parts of Eastern Europe and China) were seen to cause particular problems of influencing 
selection and development decisions, as well as day to day operational activities within the hotels. The executive from Britbuyer identified;

Speaking bluntly the Arab owners in particular are just difficult to deal with and once you put their ideal people in there you can forget about them as it will be difficult to get them out. It is a problem. ... The owners can be really very difficult.

The executives' comments also reported how local investors exerted pressure to localize management appointments at their units and argued for particular nationalities to fulfill specific roles, such as French head chefs. Such intrusions were seen to impair the development and succession planning the executives undertook to develop corporate managerial resources.

\subsection{Shared HRM interventions between international hotel companies}

In addition to the widespread core HRM practices undertaken by the companies to manage their managerial resources, two sets of differentiating practices were discerned. The best fit SHRM approach has consistently argued that strategies and competitive positions should determine people management practices to satisfy those corporate ambitions (Sanz-Valle et al., 1999; Boxall \& Purcell, 2011). However, others have also argued that the industry level provides too broad a level of analysis when attempting to understand competitive positions (Gannon, Doherty \& Roper, 2012; Panagiotou, 2006, 2008), and as such, where an industry is highly differentiated and competitive, rivalry between firms can result in the formation of what are known as strategic groups of particularly close competitors. These groups are formed through collections of firms adopting similar competitive positions and attempting to create barriers to other firms 
entering their area of the industry. When analyzing the eight company cases three specific clusters emerged based upon their analogous strategic positions (arising from their portfolio characteristics, extent of internationalization, geographical coverage, strategic business choices and market entry modes) as well as similarities in the sets of HRM practices adopted. These clusters were subsequently labeled: The Multibranders, The Mixed Portfolio Purchasers and The Prestige Operators. The third column of Table 1 also identifies the three clusters before the distinctive HRM practices of the individual companies are considered.

The Multibranders cluster was captured due to the size and scale of their multi-branded, mainly franchised and managed portfolios which allowed a critical mass of hotels in specific countries or regions of the world. These portfolios had particular implications for their recruitment policies and the spread of their managers, with strict frameworks for selection criteria for each brand developed by the corporate HR departments. They also used competency frameworks to facilitate more managerial transfers across the companies' brands aiding the corporate recognition of management talent and alleviating promotion bottlenecks in particular brands. Although this group mentioned the problems of property owner interference they were less concerned than the other firms. Their highly standardized brands meant that the majority of investors had already bought into their hotel services formula and did not wish to jeopardize their investments. The Multibranders' critical mass of units in specific countries or regions also meant that they were able to provide area HRM support to their unit managers and reinforce their brands and operating standards. This is captured in the mandatory training courses for managers of owned, managed and franchised units where attendance was obligatory. In the case of the FranchiseKing the importance of the 
training in the competency framework was emphasized for aspiring and existing unit managers:

"We have been training them in the use of Behavioural Event Interviewing to help them, where the key skills are listening and questioning, to spot the competencies. Some people seem to be naturals at it, others struggle and evaluate and judge. But it's what we're about now so we have to make sure they understand. "

The two members of the Mixed Portfolio Purchasers group had experienced considerable change and expansion following their acquisition of smaller European hotel chains, which occurred alongside substantial enhancements to their own domestic and international portfolios. The companies were struggling to reconcile these recent changes and both had divided out, and separately managed, their domestic businesses despite operating at the same market levels. There was slightly less emphasis on the strong internal labour market with figures of $75-80 \%$ quoted against the $90-100 \%$ indicated by other companies. Pressures to achieve profitable returns on their acquisitions had forced restructuring activities and the previous 'low risk' heir apparent role of deputy unit manager positions had been eliminated as a cost saving measure. These companies recruited many more Parent Company Nationals (PCNs) than the other two clusters too.

To realize the value of their acquisitions the Mixed Portfolio Purchasers had attempted to build strong, coherent corporate cultures in their newly merged organizations through extensive communication networks. Both firms had developed profiles of their hotel units (rather than their managers' or their abilities), based upon the location and size of the unit, owner relations, marketing needs, customer groups, staff relations and 
complexity and maturity of the business, to help in unit manager selection. However, these executives suggested their profiling of managers' talents were less consistent and rigorous, and still too often reliant on some subjective input. The Mixed Portfolio Purchasers were keen to undertake further growth; however, their purchases had resulted in periods of uncertainty where the effective development of their unit managerial resources had been undermined. As such this cluster is pitched somewhere between the other two clusters of IHCs, in a volatile position; having to deal with the multiple demands of realizing the asset and human resource value of their acquisitions, and assimilating effective HRM practices, whilst maintaining their positions in a highly competitive industry.

The four smaller companies of the Prestige Operators cluster reveal the widest variety of HRM practices and approaches used to develop and manage hotel managers. These companies are the most international in terms of the diversity of their portfolio of luxury hospitality facilities spread across countries. The Prestige Operators had grown substantially, internationally rather than on a national basis. They were keen to maintain their 'true international hospitality status' whilst recognizing the increased challenges involved in securing a quality supply of managerial human resources. The Prestige Operators had developed specific HRM practices to assuage these challenges and realize their strategic objectives on growth and quality standards. Their recruitment was focused primarily on securing candidates from the international hotel schools in Europe to their management development programmes. They also operated management development programmes aimed at enhancing talented managers' routes to unit manager positions, within eight to ten year periods. These programmes all espoused a clear vision of what an international manager should look like. The importance of mobility and international transfers was stressed, with international flexibility, linguistic 
ability and cultural adaptability prioritized, even for HCNs aspiring to unit management. The importance of international experience was based upon the nature of the clientele and the standards of hospitality balanced with their commitment to customize these to local traditions and preferences. Across the Prestige Operators more integration of HRM practices (succession planning, performance appraisal, training and development programmes, transfers and career management activities) was evident than in the two other clusters resulting in a higher level of consistency for identifying unit manager potential. The Globalalliance executive commented:

$$
\begin{aligned}
& \text { "How do we manage our GMs? Well we include all managers here- } \\
& \text { well it's a very integrated approach to career development, or } \\
& \text { management development and the annual appraisal, and it all comes } \\
& \text { together with succession planning and the work we co-ordinate here." }
\end{aligned}
$$

Effective management of human resources was also achieved through IT systems holding managers' details and other HR information including: mobility, succession planning, human resource planning issues, and the level of managerial talent generally. These systems allowed the Prestige Operators' HR executives more control over selection and development decisions compared to the other two clusters. The similarities in HRM practices and approaches across the Prestige Operators led to a common perception that each company was creating managerial talent which was unique and superior to their rivals. Arguments such as 'It's not what the rest of them are doing!' and 'We're producing managers who'll outplay the competition' highlight these perceptions of distinctiveness in the practices used to manage and develop international hotel managers. While these assertions do have some support, because of the more sophisticated and coherent HRM activities the Prestige Operators engaged in to ensure sufficient quantity and quality of international unit managers, much of the HRM 
practices evident were actually equivalent. The context in which HRM practices took place was more demanding for the Prestige Operator group members. The HR executives and their administrators reported more widespread issues with managing owner relations, coping with local and cultural differences, and talked in more detail about the challenges of standardizing and customizing HRM practices within and across their hotel units. These issues and concerns arise from the greater vulnerability they experienced to serving their demanding international clientele and developing partnerships through management contracts with investors. As such their industry positions as global and luxury hotel service providers indicated the necessity for a more coherent, integrated and wider range of HRM practices.

\subsection{Distinctive HRM interventions in international hotel companies}

The final column of Table 1 identifies how in addition to the similarities in HRM practices, at industry and closest rival cluster levels, distinctive HRM practices were also discernible. While all IHCs may lay claim to some distinctive HRM practices or approaches this does not suggest all firms have adopted the RBV approach. In practice only a few companies appeared to have evolved highly integrated and sophisticated HRM approaches and practices to develop and sustain their strategic human resources. FranchiseKing, Contractman International and Globalalliance stand out from their competitors in terms of their SIHRM approaches and practices due not only to the distinctive SIHRM approaches taken, and the sophistication of specific HRM practices but their attempts to bundle practices and achieve coherence and synergy between the strategies and activities of managing their strategic human resources. The strength of FranchiseKing's brands is based upon a relatively small number of company owned properties at the centre of a substantial network of franchises and management contract units. The HRM interventions used in the company's own hotels foster managers with 
intimate knowledge of FranchiseKing's prevailing and highly standardized brand standards. The managed and franchised properties benefit from this expertise where all managers are encouraged to transfer between properties and train together in these brand standards regardless of their properties' ownership status. The company's competency framework, based upon the behavioural attributes of its most successful unit managers and franchise service managers, reinforce its hierarchy of brands. FranchiseKing's successful growth and generation of profits through franchise agreements, as well as hotel revenues, meant the competency framework approach played a pivotal role in committing managers to the brand standards. This is captured by the remarks of the FranchiseKing executive: "Really our franchisees can do what they want, really, what they want. As long as they don't compromise the few things we hold dear about our brands." This philosophy facilitated through human resource transfers, training courses, newsletters and other literature, provides the company with opportunities to achieve its desired authority over the mid-market, budget and heavily branded sectors of the industry.

All the companies in the Prestige Operators group could be argued to have achieved some level of integration of their HRM practices and approaches, however, Contractman International and Globalalliance stand out as the exclusive, niche market operators doing the most here and possibly creating competitive advantage through leveraging the expertise of their managerial human resources and their management. Contractman International enjoys a great deal of status on the global stage and substantial autonomy from its parent. It also prides itself in 'leading the pack', in the design of its facilities, use of technology, cultural sensitivity and development of human resources. A distinguishing aspect of this was apparent in the preparations made for the transfer of staff at all levels across the company's portfolio. This was the only company 
that had developed or used in any form a company-wide relocation or cultural adjustment programme with the express aim of tackling culture shock issues. Opportunities for all human resources, rather than solely managers was a core theme of Contractman International's approach with its transfer, training and appraisal systems aimed at all employees. This commitment to developing human resources is evident in the executive's statement that:

"We must therefore nurture excellence in every one of our employees, especially our local nationals - the people who live in the countries where we operate hotels."

There was clear consistency and integration between these systems with a strong emphasis on international awareness and cultural adaptability along with the other more typical selection and performance criteria of an ability to work with others, demonstrating initiative, business acumen, and language proficiency. These practices were co-ordinated through advanced IT systems with the regional HR offices playing a vital role in supporting, advising and updating unit HR managers in the development and deployment of staff. The growth of the company, predicated on new build properties managed through contracts, was seen to be achievable due to a pivotal activity undertaken by regional HR functions. Each new build project instigated a labour survey, another novel HRM exercise, to identify and plan its human resource demands, and predict challenges and difficulties. In short, Contractman International took a very comprehensive and determined approach to managing its human resources on an international scale through more advanced initiatives, using HR executives in strategy development and integrating its HRM practices in a way that no other company had attempted to achieve. The underlying belief in Contractman International was to create an intangible human resource advantage due to its lack of asset value, as a 
company that did not own properties but merely managed properties for others, and traded only on the knowledge and expertise of its people.

Globalalliance's approach to managing its international unit managers takes a more elitist stance to achieve human capital advantage. It had developed a fast track development programme, which incorporated an MBA qualification and extensive international transfers and exposure across the company, far beyond the standard management development programmes outlined elsewhere. Allied to this programme was the protection afforded managers on this scheme and those in the deputy and unit manager ranks, to the extent that HR executives rather than senior operational executives had control over their appointments. Globalalliance credited the expertise of, and contribution made by its corporate HR office, by distinguishing key roles in strategy development and implementation. These views were 'part and parcel' of the devolution of much of its real estate in favour of more management contracting and marketing alliances, and substantiated by attempts to create added value and subsequently competitive advantage through its managerial resources.

Overall it seems surprising that only three of the international hotel companies had managed to foster some kind of human resource (process) advantage through the RBV approach. As the discussion highlights, however, the nature of competition in the industry may make the RBV route to competitive advantage through human resources particularly challenging.

\subsection{Discussion}


The findings highlight the degree of similarity in HRM approaches adopted by all companies, the limited extent of differentiation and the three clusters identified, and the very restricted evidence of unique differentiation in individual company HRM practices.

The best practice SHRM form or table stakes approach is seen in HRM practices which companies adopt in order to be socially legitimate in an industry (Boxall \& Purcell, 2008; Bjorkman, 2006). The drivers for table stake SHRM include the requirement to service the needs of international customers, the decision to drive market share through replica units across key locations and the limited role of technological substitution in such a people intensive service industry (Marco-Lajara \& Ubeda-Garcia, 2013; Miao et al., 2011). As such, the strong internal labour markets, training and performance appraisal HRM interventions are all based on achieving and reinforcing consistency in hospitality services and transferring proprietary knowledge. Other industry features of; US domination of the industry (Nickson, 1998), the use of management contracts as one of the prime market entry mode (Beals, 2006; Gannon, et al., 2010) and the increasing multiple brand ownership and concentration (Xiao et al., 2013) have created another set of drivers towards common HR practice. The whole sample had some aspect of American heritage, either through original ownership or subsequent acquisition and partnerships, and had adopted management contracting or franchising as the preferred low equity expansion strategy (Nickson, 1998; Xiao et al., 2013). Placed alongside HRM's American ancestry (Boselie et al., 2009; Brewster, 2007) the evidence suggests that the management of unit managers in this sector is particularly strongly influenced by industry cultural and institutional factors, in addition to the typical parent and host country factors (Hodari \& Sturman , 2014). The HRM implications can be seen most clearly in the shared challenges of working with property owners/investors with 
different cultural conventions and the intensive corporate communication attempts to maintain brand standards across hotel portfolios (Beals, 2006).

The nature of the managerial human resources themselves also promotes convergence in HRM practices across the industry. The belief that unit managers need to be business people rather than solely hoteliers was a common theme across the company case studies and reflected the changing nature of the industry. However, the companies still recruited mainly from specialised hospitality programmes and were reluctant to take on management recruits who did not 'know' the industry. The international hotel schools that provided the main pools for management recruitment did at least fulfill some of the international requirements though they also created a relatively homogenous human resource that may inhibit change and innovation in the sector (Gannon et al., 2010). The similarities in HRM interventions reinforce the arguments that specific people management practices occur, not only in response to common industry challenges, but also in order to serve to legitimise industry membership (Boxall \& Purcell, 2011; Leonard-Barton, 1995). This version of the best practice SHRM approach verifies at least some of claims of the best practice protagonists that certain HRM practices are competitively important (Pfeffer, 1998; Huselid, 1995). However, it also shows that these practices are not the sole determinants for organisational success but fulfill one aspect of firms' performance measures, the need to be socially legitimate and to conform to industry standards in order to succeed and survive (Boxall \& Purcell, 2008; Paauwe, 2008; Bjorkman, 2006). This means that some HRM practices are not created for competitive advantage but for competitive endurance and they exist to ensure survival within an industry. This evidence of human resource 'table stake best practices' (Leonard-Barton, 1995) operating at the international level within a particular industry highlights the complexity of forces acting upon international companies. 
In terms of detecting the 'best fit' SHRM approach where HRM practices were driven by companies' strategies and market positions, some novel findings emerged. The executives talked about the ways in which their HRM practices were based upon their own company's strategies, portfolio characteristics and market positions. However, amongst the eight cases, three clusters surfaced with common HRM practices and policies aligned with their similar market positions, portfolio characteristics and strategies. Within the Prestige Operator, Mixed Portfolio Purchaser and Multibrander clusters different branding approaches shaped their investment and operating priorities and consequently their ways of articulating the management skills required to deliver their brands. The clusters also differed on the basis of their organization and structure, and international management orientations affecting their choice of recruitment pools, at local, regional, national and international levels. The various modes of growth and market entry expertise of the three clusters consequently led to a different emphasis in managerial skills and knowledge. For example the Prestige Operators highlighted their unit managers as capable of managing (difficult) property owners whilst the Multibranders encouraged management expertise in operating highly standardized hospitality services and disseminating that knowledge to others (franchisees and partners). These findings show that the 'best fit' SIHRM approach can be applied to companies' closest industry rivals because they face similar HRM dilemmas due to their common business and operational predicaments. Such findings indicate another level of institutional assimilation and conformity amongst the strategies and HRM practices of the closest rivals in industries (Oliver, 1997; Boxall \& Purcell, 2011). This evidence strongly reinforces the view that more research needs to be undertaken on such clusters of close rivals' adoption of HRM practices and their relationship to the strategic group 
literature featured in the strategic management literature (Gannon et al., 2012; Short et al., 2007; Panagiotou, 2006; 2008).

The evidence of pressures on companies to conform due to industry institutional conventions is also part of the critique on the RBV SHRM approach (Boxall \& Purcell, 2008; Paauwe, 2008; Oliver, 1997). Within this study surprisingly little evidence of the RBV was found as just three out of the eight companies deployed unique HRM practices, integrated with other aspects of their HRM or broader corporate and business strategies, to create competitive advantage. Contractman International, FranchiseKing and Globalalliance had a very clear sense of what they were good at, where those strengths lay in their resources and practices, and how they could be built upon and leveraged. It was not just the case that these companies' managerial knowledge and skills and HRM practices were aligned with their internationalization strategies but that these strategies and practices had been based upon the existing managerial and executive expertise to create advantage (Morris et al., 2006). These companies were also investing in HRM practices and processes that were particular to their strategic needs in an attempt to sustain their competitive advantage and render imitation by their competitors more difficult. That only three companies demonstrated any semblance of the RBV SHRM approach suggests that although firms use rhetoric to suggest that they strive for competitive distinction and 'do things differently', through their human resources and associated practices, in reality the pressures for conformance are strong (Marco-Lajara \& Ubeda-Garcia, 2013; Bjorkman, 2006). Specifically within the international hotel industry, it is not only the table stake approach issues, identified above, but also another level of conformity, identified through these clusters of closest 
competitors, which limit companies' capacity to create and leverage distinctive human resources and HRM practices which differentiate themselves (via the RBV approach). Earlier in this article some discussion was offered about the forces for customization and standardization in international HRM. The findings presented here offer limited support for existing research literature (Boselie, et al., 2003). One explanation for the degree of standardization found across the HRM practices is the focus on managers (as opposed to lower levels of employees (Easterby-Smith et al., 1995; Rosenzweig, 2006)), the US origins of the companies (Ferner \& Quintanilla, 1998; Nickson, 1998) and low level of entrenchment of the hotel industry in national business institutions (Boselie et al., 2003; Edwards et al., 2010) also compound this consistency. However, set against this we might have expected the low to moderate interdependence between subsidiaries and parent companies (due to the market entry modes used), and the cultural distance between the headquarters of the parent company and the countries of operation to have acted as competing forces for customization (Edwards et al., 2010). In the international hotel industry these localizing influences seem to be outmaneuvered by the origins, power and growth methods of the international brands in driving standardization (Xiao et al., 2012). Even so, there is one localizing force that has emerged as being of particular importance in the management of unit managers. This is the influence of local property owners who often influence and inhibit human resource decisions and practices. Their impact means companies are not always able to manage their human resources in line with their objectives of building and transferring proprietary knowledge and expertise through managerial resources (Hodari \& Sturman, 2014; Beals, 2006). 
Finally, in terms of the arguments surrounding the convergence-divergence debate, the findings show clear indications of standardization in HRM practices in the international hotel industry. As Brewster (2006 p.83) argues however, this does not condemn all HRM practices in an industry to inevitable assimilation, as "there is a continual tension between isomorphic pressures for similarity and the local resistance to such pressures". The opportunity to identify and analyze different levels of competition associated with survival, market positioning and competitive advantage in an industry can help understand this continual tension (Paauwe, 2008).

\subsection{Conclusions}

This study set out to explore the evidence for a hybrid version of SIHRM approaches within a highly competitive and operationally complex, international industry. The findings provide evidence for this hybrid version of SIHRM approaches and the importance of industry factors in shaping opportunities and challenges for competitive advantage through human resources (Boxall \& Purcell, 2011; Boselie et al., 2009).

In this industry, companies appear not to adhere to only one of the three main SHRM approaches (best practice, 'best fit' and RBV) when they seek to achieve competitive advantage through their human resources. In line with more recent theoretical arguments the eight IHCs tend to adopt very similar HRM practices in their management of the subsidiary managers, who constitute their strategic human resources (Boxall \& Purcell, 2011), due to the complex and competitive environments in which these firms operate (Hodari \& Sturman, 2014; Miao et al., 2011; Xiao et al., 2012). However, this study also shows that few companies successfully adopted a hybrid of all three SHRM approaches - in particular, only three firms displayed practices which were characteristic of the RBV approach. There was considerable evidence of the 
simultaneous adoption of both industry-wide 'table stake' practices, together with 'bestfit' at the level of the closest industry rival clusters, akin to the strategic groups acknowledged in the strategic management literature. Overall, more common practice than differentiated HRM practice was found and the extent of the commonality was derived from the similarity of the institutional forces exerted on the companies both at the industry and closest rival levels. This rendered it difficult for the companies to differentiate themselves in inimitable ways through their managerial human resources and their HRM practices as expected in the RBV SHRM approach. Key to these specific industry forces was the US domination of the corporate hotel industry, the predominant use of low risk market entry modes and the homogeneity of the managerial labour pool (Gannon et al., 2010; Miao et al., 2011).

An important theoretical implication arising from this study is that competitive advantage through human resources is clearly more challenging for some industries than others though a hybrid version of the SHRM approaches adopted in an industry offers valuable insights into why this is, along with relevant practical implications. Executives and managers of companies within industries that face substantial pressures for institutional assimilation and restraints on market entry modes must recognize how opportunities for differentiation are inhibited. With the continued use of low or nonequity market entry modes in the hotel industry executives must be clear about the asset and wider strategic implications, as well as the opportunity costs concerned.

This study identifies that where companies derive competitive advantage from their human resources and HRM practices, they have closely aligned their managers' expertise with their corporate market entry mode expertise and developed some distinctive, complex and integrated HRM interventions, which have a mutually 
reinforcing effect. The managerial implications are then that corporate executives may find understanding what they can leverage internally in terms of their managerial resources and HRM practices beneficial for achieving competitive advantage, however, in addition it seems they need to focus upon differentiating themselves from their closest rivals. A further implication also surfaces here and indicates that there are opportunities to explore how closest rivals or strategic groups, as identified in the strategic management literature, impact upon HRM strategies and practices to achieve competitive advantage (Gannon et al., 2012; Short et al., 2007; Panagiotou, 2006). This study indicates that given the ongoing quest for sustained competitive advantage, arguments that human resources accrue added value and increasing internationalization, further research concerning HRM practices and strategies at industry and sub-industry levels is clearly warranted.

Despite the important insights of this article it is apposite to reflect upon its limitations. The primary limitation is the focus on senior HR executives and their teams as the main respondents as additional insights from non-HR executives could have elaborated further upon the strategic value, deployment and development of unit managers. However, issues of wider access and resources (time and money) precluded such ambitions and the participation of the most senior HRM executives of the companies meant that a detailed level of insight into the industry, the companies and the management of subsidiary managers was achieved. The breadth of data sources, access and level of engagement with administrative and executive HRM respondents does compensate for the limited number of key respondents due to their significant strategic roles. Future research would, however, benefit from respondent participation across a wider range of functions at the senior executive levels and should pursue the links between SHRM and the nature of micro-foundations (Minbaeva, 2013). 


\section{References:}

Adler, N. J., \& Ghadar, F., 1990. Strategic Human Resource Management: A Global Perspective. In R. Pieper (ed.), Human Resource Management in International Comparison, De Gruyter, Berlin/New York.

Barney, J.B., 2001. Resource-based theories of competitive advantage: A ten-year retrospective on the resource based view. Journal of Management, 27, 643-650.

Bartlett, C., \& Ghoshal, S., 1989. Managing Across Borders: The Transnational Solution. Hutchinson, London.

Bartlett, C., \& Ghoshal, S., 2000. Transnational Management. ( $3^{\text {rd }}$ ed.); Irwin McGrawHill, Boston, MA

Beals, P., 2006. Hotel asset: management: will a North American phenomenon expand internationally? In Harris, P. \& Mongiello, M. (Eds.), Accounting and Financial Management: Developments in the International Hospitality Industry. Butterworth Heinemann, Oxford.

Beer, M., Spector, B., Lawrence, P.R., Mills, D.Q., \& Walton, R.E., 1984. Managing Human Assets. Free Press, New York.

Bjorkman, I. 2006. International human resource management research and institutional theory. In Bjorkman, I. \& Stahl, G.K. (eds.), Handbook of Research in International Human Resource Management, Edward Elgar, Cheltenham, UK.

Boon, C., Paauwe, J., Boselie, P., \& Den Hartog, D., 2009. Institutional pressures and HRM: developing institutional fit. Personnel Review, 38 (5), 492-508

Bonache, J., \& Zagarty-Oberty, C., 2008. Determinants of the success of international assignees as knowledge transferors: a theoretical framework. International Journal of Human Resource Management, 19 (1), 1-18.

Boselie, P., Brewster, C., \& Paauwe, J., 2009. In search of balance - managing the dualities of HRM: an overview of the issues. Personnel Review, Guest editorial, 38 (5), 461-471

Boselie, P., Paauwe, J., \& Richardson, R. 2003. Human Resource Management, institutionalization and organizational performance: a comparison of hospitals, hotels and local government. International Journal of Human Resource Management, 14 (8) 1407-1429.

Boxall, P., \& Steeneveld, M., 1999. Human Resource Strategy and Competitive Advantage: A Longitudinal Study of Engineering Consultancies. Journal of Management Studies, 36 (4), 443-463

Boxall, P., \& Purcell, J., 2011. Strategy and Human Resource Management, $3^{\text {rd }}$ edition, Palgrave Macmillan, Basingstoke 
Boxall, P., \& Purcell, J., 2008. Strategy and Human Resource Management, $2^{\text {nd }}$ edition, Palgrave Macmillan, Basingstoke

Brewster, C., 2007. Comparative HRM: European views and perspectives. International Journal of Human Resource Management, 18 (5), 769-787.

Brewster, C., 2006. Comparing HRM policies and practices across geographical borders In G.K. Stahl, \& I. Bjorkman, (Eds.), Handbook of Research in International Human Resource Management, Edward Elgar, Cheltenham, UK.

Bryman, A., \& Bell, E., 2007. Business Research Methods, $2^{\text {nd }}$ edition, Oxford University Press, Oxford.

Easterby-Smith, M., Malina, D., \& Yuan, L., 1995. How culture sensitive is HRM? A comparative analysis of practice in Chinese and UK companies, International Journal of Human Resource Management, 6 (1), 31-59.

Edwards, T. et al. 2010. Multinational companies and the diffusion of employment practices from outside the country of origin - Explaining variation across firms.

Management International Review, 50 (5), pp. 613-634

Ferner, A., \& Quintanilla, J., 1998. Multinationals, business systems and HRM: the enduring influence of national identity or a process of Anglo-Saxonization, International Journal of Human Resource Management, 9 (4), 710-731.

Fombrun, C., Tichy, N.M., \& Devanna, M.A. (Eds.), 1984. Strategic Human Resource Management, Wiley, New York.

Foss, N.J., 2011. Invited Editorial: Why Micro-Foundations for Resource-Based Theory are Needed and What They May Look Like, Journal of Management, 37 (5), 1413-1428

Gannon, J.M. Doherty, L. \& Roper, A., 2012. The role of strategic groups in understanding strategic human resource management, Personnel Review, 41 (4), 513546

Gannon, J., Roper, A., \& Doherty, L., 2010. The impact of hotel management contracting on IHRM practices: Understanding the bricks and brains split, International Journal of Contemporary Hospitality Management, 22 (5), 638 - 658

Harvey, M.G., Novicevic, M.M., \& Speier, C., 2000. Strategic Global Human Resource Management: The role of Inpatriate Managers, Human Resource Management Review, $10(2), 153-175$.

Heenan, D.A., \& Perlmutter, H.V., 1979. Multinational Organization Development, Addison-Wesley, Reading M.A.

Hodari, D. \& Sturman, M.C. 2014. Who's in Charge Now? The Decision Autonomy of Hotel General Managers, Cornell Hospitality Quarterly, 55 (4) 433-447 
Huselid, M., 1995. The impact of human resource management practices on turnover, productivity and corporate financial performance, Academy of Management Journal, 38 (3), 635-72.

Leonard-Barton, D., 1995. Wellsprings of Knowledge: Building and Sustaining the Sources of Innovation, Harvard Business School Press, Boston, Massachusetts.

Kaufman, B., 2014. The Development of Human Resource Management across Nations: Unity and Diversity, Edward-Elgar, Cheltenham.

Magnini, V., 2008. Practising effective knowledge sharing in international hotel joint ventures, International Journal of Hospitality Management, 27 (2), 249-258.

Marchington, M., Carroll, M., \& Boxall, P., 2003. Labour scarcity, the resource-based view, and the survival of the small firm: a study at the margins of the UK road haulage industry, Human Resource Management Journal, 13 (4), 5-22.

Marco-Lajara, B. \& Ubeda-Garcia, M. 2013. Human resource management approaches in Spanish hotels: An introductory analysis. International Journal of Hospitality Management 35, 339-347

Marler, J.H. 2012. Strategic Human Resource Management in Context: A Historical and Global Perspective, Academy of Management Perspectives Symposium, May, 6-11

Miao, L. Adler, H. \& Xu, X. 2011. A stakeholder approach to expatriate management: Perceptions of expatriate managers in China. International Journal of Hospitality Management. 30, 530-541

Minbaeva, D.B. 2013. Strategic HRM in building micro-foundations of organizational knowledge-baed performance. Human Resource Management Review, 23, 378-390

Morris, S.S., Snell, S.A., \& Wright, P.M., 2006. A resource-based view of international human resources: towards a framework of integrative and creative capabilities, In G.K.Stahl, \& I. Bjorkman, (Eds.), Handbook of Research in International Human Resource Management, Edward Elgar, Cheltenham, UK.

Nickson, D., 1998. A Review of Hotel Internationalisation with a Particular Focus on the Key Role Played by American Organisations, Progress in Tourism \& Hospitality Research, 1 (4), 53-66.

Oliver, C., 1997. Sustainable Competitive Advantage: Combining Institutional and Resource-based views, Strategic Management Journal, 18 (9), 697-717.

Paauwe, J. 2009. HRM and performance: achievements, methodological issues and prospects. Journal of Management studies, 46(1), 129-142.

Paauwe, J., \& Boselie, P., 2003. Challenging 'strategic HRM' and the relevance of the institutional setting, Human Resource Management Journal, 13 (3), 56-70. 
Panagiotou, G., 2008. Conjoining prescriptive and descriptive approaches: Towards an integrative framework of decision making: A conceptual note, Management Decision, 46 (4), 553-564.

Panagiotou, G., 2006. Managerial cognitions of competitive environments: a strategic group analysis, Management Research News, 29 (7), 439-456.

Patton, M.Q. 2002. Qualitative research and evaluation methods. $3^{\text {rd }}$ ed Sage.

Pfeffer, J., 1998. The Human Equation: Building Profits by Putting People First, Harvard Business School Press, Boston, MA.

Pinnington, A.H., 2011. Strategic Management and IHRM, Chapter 1 in Harzing, A. \& Pinnington, A.H. (eds). International Human Resource Management, Sage, London, 1346.

Pisani, N., 2009. International Management Research: Investigating its Recent Diffusion in Top Management Journals, Journal of Management, 35, 199- 218.

Rosenzweig, P.M., 2006. The dual logics behind international human resource management: pressures for global integration and local responsiveness, In G.K.Stahl, \& I. Bjorkman, (Eds.), Handbook of Research in International Human Resource Management, Edward Elgar, Cheltenham, UK.

Sanz-Valle, R., Sabater-Sanchez, R., \& Aragon-Sanchez, A. (1999). Human Resource management and business strategy links: an empirical study, International Journal of Human Resource Management, 10: 4, 655-671.

Schuler, R., \& Jackson, S., 1987. Linking competitive strategy and human resource management practices, Academy of Management Executive, 3 (1), 207-219.

Short, J.C., Ketchen, D.J., Palmer, T.B., \& Hult, G.T.M., 2007. Firm, Strategic Group, and Industry Influences on Performance, Strategic Management Journal, 28 (1), 147 167

Teece, D.J. 2007. Explicating Dynamic Capabilities: The Nature and Microfoundations of (Sustainable) Enterprise Performance. Strategic Management Journal. 28, 1319-1350

Thite, M., Wilkinson, A. \& Shah, D. 2012. Internationalization and HRM strategies across subsidiaries in multinational corporations from emerging economies - A conceptual framework. Journal of World Business. 47, 251-258.

Thomas, G. 2011. A typology for the case study in social science following a review of definition, discourse, and structure. Qualitative Inquiry, 17(6), 511-521.

Xiao, Q. O'Neill, J.W. \& Mattila, A.S. 2012. The role of hotel owners: the influence of corporate strategies on hotel performance. International Journal of Contemporary Hospitality Management. 24 (1) 122-139

Zhong, B-J., Morris, S. S., Snell, S. A., \& Wright, P. M. 2012. Resource-based view of 
international human resources: The role of integrative and creative capabilities in gaining competitive advantage for MNCs. In G. Stahl, I. Bjorkman, and S. Morris (eds.) Handbook of Research in International Human Resource Management. Edward Elgar. 
Appendix 1. Initial Survey Questions

1. . In your role as Human Resources Director please describe your areas of responsibility. (For example, Are you responsible for human resource management of; a specific geographical area, a particular corporate brand ?)

Geographical Area

Brand

Other

1i. Are you responsible for the recruitment, selection, deployment and development of unit general managers in your company?

$\mathrm{Y}$

$\mathrm{N}$

2. Which of these basic human resource activities does your position comprise?

(Please tick as appropriate)

a. Human Reources Strategy

b. Succession Planning

c. Recruitment

d. Selection

e. Training \& Developing

f. Performance Appraisals

g. Career Counselling

h. Other

(Please specify)

3. Does your company have any of the following human resource planning tools for unit management positions?

a. Succession planning system

b. Talent bank of managers details

c. Corporate management

development programme for graduates

d. Fast-track international management scheme

e. Mentoring programme

f. Career Counselling scheme
Y

$\mathrm{N}$

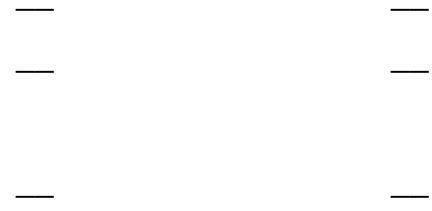

-

$-$ 
4. What selection methods does your company use for unit management positions?

a. Interview panel

b. Recommendations from senior managers

c. Psychometric tests

d. Assessment centres

e. Previous performance appraisal results

f. Other, please state

$\mathrm{Y}$

$\mathrm{N}$

5. How often are managers in unit positions appraised?
a. Once every two years
b. Once a year
c. Twice a year
d. More than twice a year
e. Other, please state

5i. Who appraises managers in unit positions?

6. Does your company use any of the following human resource processes for those in unit management positions?

Y

$\mathrm{N}$

Sometimes
a. International experience schemes
b. Cross-functional experience schemes
c. Formal career plans
d. Mentoring schemes
e. Corporate management training courses
f. Languages and cultural training courses

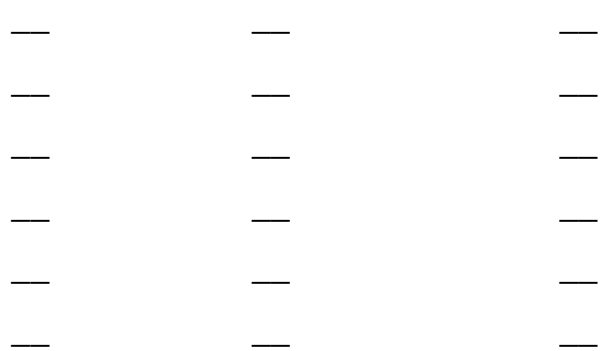

7. What criteria does your company use to select managers for international postings?

Please rate the criteria identified, 1 for most important through to 7 for least important.
a. Foreign language ability
b. Performance appraisal results
c. Training courses attended
d. Recommendations from senior managers
e. Managers own career aspirations
f. Previous international experience
g. Other, please state

Y

N Rating

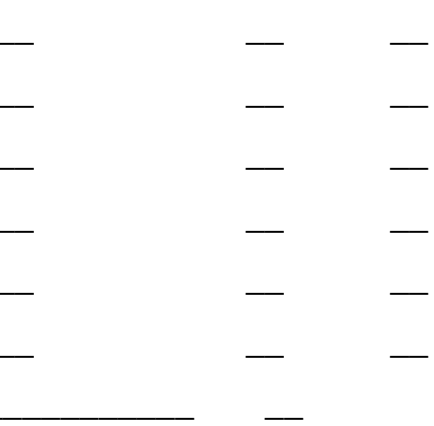


Table 1. Summary of IHCs and their HRM practices across the sample, closest rival clusters and company specific approaches

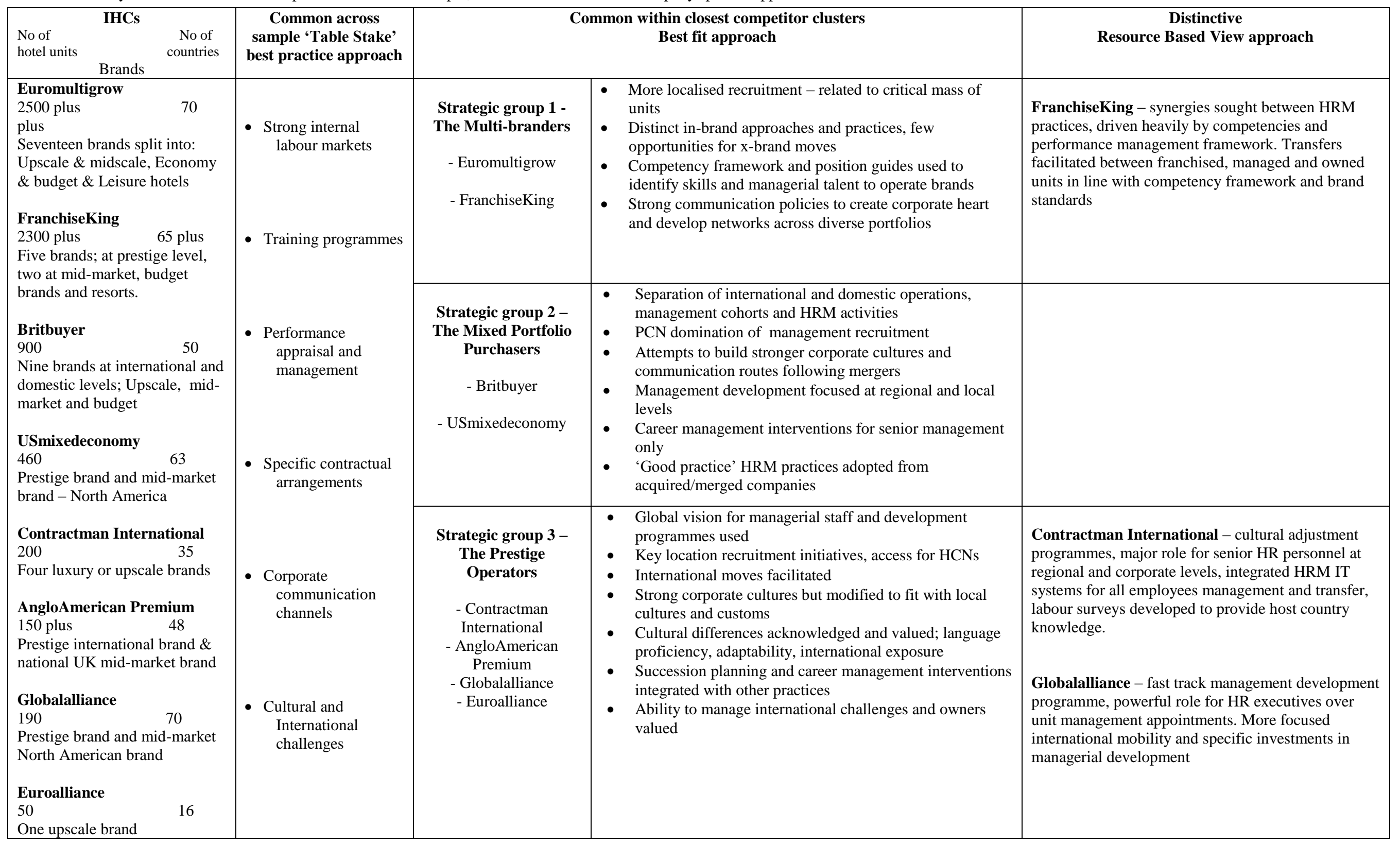

